\title{
Comparison of antianginal efficacy of one conventional and three long acting beta-adrenoreceptor blocking agents in stable angina pectoris
}

\author{
G R JONES, M A MIR
}

From the Department of Medicine, Welsh National School of Medicine, University Hospital of Wales, Heath Park, Cardiff

SUMMARY We compared the antianginal efficacy of one conventional and three long acting beta-adrenoreceptor blocking agents in a randomised manner in 12 patients with stable angina pectoris. An exercise test was performed initially and in the 24th hour after a single daily dose of 160 $\mathrm{mg}$ of each beta-blocker at the end of a two week treatment period. In addition, glyceryl trinitrate consumption, anginal attack rate, and activity scores were recorded. No titration studies to an equivalent degree of beta-blockade were undertaken; a fixed dose was used even though these drugs are not equipotent.

Conventional propranolol in a single daily dose of $160 \mathrm{mg}$ was as effective in controlling the frequency of anginal attacks as long acting propranolol and sustained release oxprenolol. Exercise tolerance was less with sustained release oxprenolol than with conventional propranolol, long acting propranolol, and nadolol. Nadolol produced a significantly greater reduction in exercise-induced tachycardia than did long acting propranolol, sustained release oxprenolol, and conventional propranolol, and also the lowest anginal attack rate, the lowest trinitrin consumption, and significantly less ST segment depression than the other three.

These findings.suggest that nadolol is more potent than long acting propranolol, sustained release oxprenolol, and conventional propranolol, and the antianginal benefit at the 24th hour relates to the degree of beta-adrenoreceptor blockade achieved.

Conventional beta-adrenoreceptor blocking drugs are given divided into three or four daily doses because of their short serum half-life. Recently, various long acting preparations have been introduced with the expectation that a single daily dose would provide a sustained antianginal effect, ensure 24 hour betaadrenoreceptor blockade, and achieve improved patient compliance. So far no clinical study has shown any improvement in the antianginal effect of a divided dose regimen, as compared with the same dose taken on a single once-daily basis. It also remains to be established that the antianginal effect of a long acting beta-adrenoreceptor blocking drug extends its antianginal efficiency to the 24th hour before the next dose is due.

This study was undertaken to compare four betaadrenoreceptor drugs for their antianginal efficiency in the 24th hour after a single daily dose treatment period. Propranolol was used to represent a convenReceived for publication 26 May 1981 tional beta-adrenoreceptor blocker: the three other preparations were chosen because in each case the mechanism for a prolonged serum half-life was different.

\section{Patients and methods}

PATIENTS

Twelve patients with an average age of 56 years (range 39 to 71) with stable angina pectoris were studied. In all of these carefully selected patients, angina could be reproduced during bicycle (ergometer) exercise and in all cases ST depression of more than $1 \mathrm{~mm}$ for $0.8 \mathrm{~s}$ duration on V5 developed. None of the patients had any evidence of heart failure. Eleven patients had been taking a beta-adrenoreceptor blocking drug for more than six months and the twelfth patient was started on long acting propranolol six weeks before his entry into this study. The dose of the drug in each was $160 \mathrm{mg}$ either in divided doses or as a long acting 
Table 1 Comparison of patient well-being, job, social, and home activity ${ }^{\star}$ scores between pretrial therapy and four beta-adrenoreceptor drugs

\begin{tabular}{|c|c|c|c|c|c|c|c|c|}
\hline \multirow{2}{*}{$\begin{array}{l}\text { Patient No. and } \\
\text { pretrial treatment }\end{array}$} & \multicolumn{2}{|c|}{ Slow release oxprenolol } & \multicolumn{2}{|c|}{ Long acting propranolol } & \multicolumn{2}{|l|}{ Nadolol } & \multicolumn{2}{|c|}{ Conventional propranolol } \\
\hline & Well being & Activity & Well being & Activity & Well being & Activity & Well being & Activity \\
\hline 1 SRO & & & & & & & & \\
\hline $\begin{array}{ll} & 160 \mathrm{mg} \text { od } \\
2 \mathrm{SRO}\end{array}$ & 6 & 12 & 7 & 13 & 7 & 9 & 7 & 15 \\
\hline $\begin{array}{c}160 \mathrm{mg} \text { od } \\
3 \text { Oxprenolol }\end{array}$ & 5 & 10 & 9 & 6 & 5 & 9 & 10 & 15 \\
\hline $\begin{array}{l}80 \mathrm{mg} \mathrm{bd} \\
4 \mathrm{LAP}\end{array}$ & 8 & 11 & 8 & 16 & no data & & 8 & 11 \\
\hline $\begin{array}{l}160 \mathrm{mg} \text { od } \\
5 \text { Oxprenolol }\end{array}$ & 4 & 17 & 5 & 8 & 2 & 6 & 5 & 12 \\
\hline $\begin{array}{l}80 \mathrm{mg} \text { bd } \\
6 \mathrm{SRO}\end{array}$ & 7 & 12 & 4 & 12 & 4 & 10 & 6 & 13 \\
\hline $\begin{array}{l}160 \mathrm{mg} \text { od } \\
7 \mathrm{LAP}\end{array}$ & 6 & 12 & 4 & 9 & 7 & 10 & 6 & 12 \\
\hline $\begin{array}{l}160 \mathrm{mg} \text { od } \\
8 \mathrm{LAP}\end{array}$ & 7 & 13 & 6 & 12 & 9 & 18 & 8 & 18 \\
\hline $\begin{array}{l}160 \mathrm{mg} \text { od } \\
9 \mathrm{CP}\end{array}$ & 8 & 18 & 6 & 12 & 5 & 12 & 6 & 12 \\
\hline $\begin{array}{l}40 \mathrm{mg} \text { qds } \\
10 \mathrm{SRO}\end{array}$ & 6 & 13 & 4 & 11 & 8 & 13 & 5 & 10 \\
\hline $\begin{array}{l}160 \mathrm{mg} \text { od } \\
11 \text { Oxprenolol }\end{array}$ & 7 & 16 & 8 & 14 & 8 & 14 & 6 & 13 \\
\hline $\begin{array}{l}40 \mathrm{mg} \text { qds } \\
12 \mathrm{LAP}\end{array}$ & 7 & 12 & 8 & 12 & 6 & 12 & 6 & 12 \\
\hline $160 \mathrm{mg}$ od & 10 & 18 & 4 & 8 & 6 & 8 & 8 & 18 \\
\hline Mean & $\begin{array}{l}7 \\
\text { Worse }\end{array}$ & $\begin{array}{l}13 \\
\text { Worse }\end{array}$ & $\begin{array}{l}6 \\
\text { No change }\end{array}$ & $\begin{array}{l}11 \\
\text { Better }\end{array}$ & $\begin{array}{l}6 \\
\text { No change }\end{array}$ & $\begin{array}{l}11 \\
\text { Better }\end{array}$ & $\begin{array}{l}7 \\
\text { Worse }\end{array}$ & $\begin{array}{l}13 \\
\text { Worse }\end{array}$ \\
\hline
\end{tabular}

* For explanation see methods.

SRO, slow release oxprenolol; LAP, long acting propanolol; CP, conventional propranolol.

preparation (Table 1), since most patients with angina tend to respond to this dose. ${ }^{1-5}$ None of the patients was taking digitalis or a diuretic. Two patients smoked cigarettes. Smoking habits remained unchanged throughout the study. No cigarettes were allowed the morning before the tests were performed.

The purpose and the nature of the investigation was explained to each patient and all consented to participate in the study.

\section{DESIGN OF INVESTIGATION}

The exercise procedure was essentially in accordance with the one designed by Redwood et al. ${ }^{6}$ All patients were brought to the exercise laboratory (temperature $20^{\circ}$ to $24^{\circ} \mathrm{C}$ ) on at least three weekly occasions before the definitive studies. They exercised upright on a bicycle ergometer (Monark, Sweden) and pedalled steadily in time with a metronome at $50 \mathrm{rpm}$. The exercise capacity was assessed by increasing the work load by 300 kilopondmetres (kpm) every four minutes until the onset of angina. The heart rate was monitored continuously through a V5 lead. Each patient was entered into the study after the anginal point had become reproducible. On the day of the definitive test, the patients were studied in the morning after 30 minutes rest, and asked not to take any glyceryl trinitrate (GTN) on that day. Each patient was exercised exactly 23 hours after the last dose of a beta-adrenoreceptor blocker. At the point of onset of angina the total exercise load, duration of exercise, and heart rate were recorded. A 12 lead electrocardiogram was taken before and within two minutes of the exercise. ST segment depression in all leads ( $\mathrm{ST}$ ) was documented. This exercise procedure was carried out at the entry of a patient into the study, at each cross over point, and at the end of the study.

Four beta-adrenoreceptor blocking agents, conventional propranolol, long acting propranolol, sustained release oxprenolol, and nadolol were studied. Propranolol was chosen as a conventional betaadrenoreceptor blocking drug with a short serum half-life. The three long acting preparations achieve a long serum half-life by different mechanisms: long acting propranolol allows slow diffusing of the active drug from microspheres, in slow release oxprenolol, oxprenolol is leached out of a polymer colander, and 
nadolol has an intrinsically long plasma half-life, being slowly excreted. ${ }^{7}$ Each drug was administered in a single morning dose of $160 \mathrm{mg}$ as this is a likely dosage to be used in clinical practice, though, dose for dose, nadolol is a slightly more potent drug than propranolol. ${ }^{8}$ Unfortunately, identical capsules could not be obtained but "double-blindness" was maintained by providing each patient with a two week supply in an unlabelled bottle so that neither the investigator nor the patient knew the exact identity of the drug inside the bottle. The patients were randomised and each received a bottle for each period identified by its period number. The bottles were collected at the end of each cross over period and stored until the end of the study; these were then checked for unused drugs. The code key was sealed until the end of the study.

\section{PATIENT ASSESSMENT}

At the start of each treatment period the patients were given record cards to note the number of anginal attacks and glyceryl trinitrate consumption. They also noted whether they had to reduce, or if they could increase, the level of a named activity at home (for example sewing, running, digging, etc.), socially (for example dancing, playing games, etc.), and at work (for example climbing stairs, etc.). A weekly pointscoring system was designed by which a no-change in any activity was awarded 2 . Thus, in each two week period a patient scored 12 if he noticed no change in any of the three activities, six if he could undertake an additional activity in each, and 18 if he noticed a deterioration in social, home, and job activities. These data were analysed by Friedman's test. ${ }^{9}$

\section{LABORATORY MEASUREMENTS}

Routine laboratory investigations were carried out in all patients. Blood was collected for plasma betablocker levels 23 hours after the last dose in each patient at the time of the exercise test, and the plasma was stored at $-20^{\circ} \mathrm{C}$. Plasma concentrations of drugs were measured by the respective pharmaceutical laboratories.

STATISTICAL METHODS

Conventional statistical methods were used. Anginal attacks, glyceryl trinitrate consumption, and scores for activity and well-being were analysed by a nonparametric method using Friedman's rank test. ${ }^{9}$ Changes in heart rate, $2 S T$ depression, and work load were studied by analysis of variance fitting for patient, period, treatments, and carryover. Significance was assessed by using an ' $F$ ' test after which, if significant, $t$ tests were used ${ }^{10}$ to compare pairs of treatments, using the residual mean square in the estimate of the standard error.

\section{Results}

\section{ANTIANGINAL EFFICIENCY}

The glyceryl trinitrate consumption and anginal attack rate were lowest during the nadolol period of two weeks (Table 2). Patients were able to increase their activity either at home, at work, or socially during the nadolol and long acting propranolol periods. The score for these activities was better during nadolol and long acting propranolol, as compared with pretrial and conventional propranolol periods (Table 1). The sense of well-being was not easy to define, but the patients complained that though the anginal frequency was not significantly different between various periods, the attacks tended to occur in clusters in the evening and early morning during conventional propranolol and slow release oxprenolol as opposed to long acting propranolol and nadolol periods.

\section{EXERCISE PERFORMANCE}

The maximal exercise performance to the point of angina was not significantly different between propranolol, long acting propranolol, and nadolol (Fig. 1), but the mean kpm achieved was lowest during slow release oxprenolol and highest during nadolol. Interestingly, 23 hours after a single dose of conventional propranolol, the exercise performance was as good as long acting propranolol and better than slow release oxprenolol.

The mean resting heart rate 23 hours after the last dose of nadolol was significantly lower $(p<0.05)$ at $57 \pm 4 \mathrm{bpm}(\mathrm{SEM})$ than with slow release oxprenolol and conventional propranolol (Fig. 2). The mean resting pulse rate was $63 \pm 4 \mathrm{bpm}$ during long acting propranolol, $70 \pm 4 \mathrm{bpm}$ during slow release oxprenolol, and $71 \pm 6 \mathrm{bpm}$ during conventional propranolol. There was no significant difference between these three. The exercise-induced tachycardia at the anginal point was lowest after nadolol ( 93 bpm) and the difference between nadolol and the two other long acting beta-blockers was highly significant $(\mathrm{p}<0.01)$. The two long acting formulations, slow release oxprenolol and long acting propranolol, also

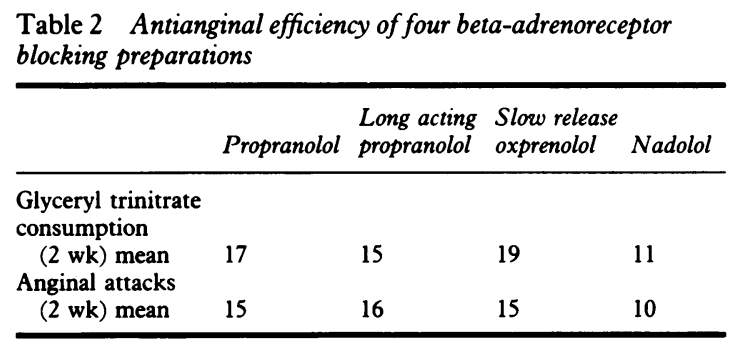




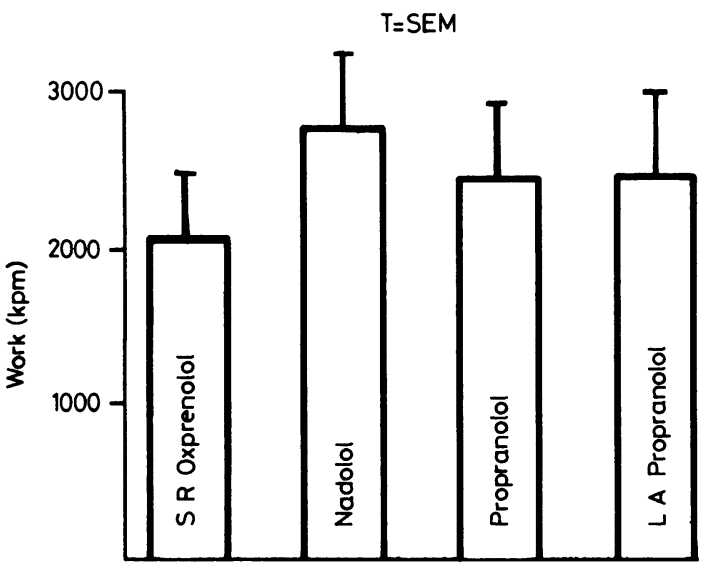

Fig. 1 Comparison of exercise performance of four betaadrenoreceptor drugs in the 24th hour after two weeks of a single daily dose treatment.

showed a significant reduction in exercise induced tachycardia as compared with conventional propranolol). The mean heart rate at the onset of angina was $115 \pm 4 \mathrm{bpm}$ after slow release oxprenolol, $107 \pm 3$ bpm after long acting propranolol, and $130 \pm 4 \mathrm{bpm}$ after conventional propranolol.

\section{¿ST SEGMENT DEPRESSION}

The mean of the total ST segment depression in all leads ( $(\mathrm{ST}$ ) after exercise was $2 \cdot 13 \pm 0 \cdot 41$ (SEM) $\mathrm{mm}$ 23 hours after nadolol, $4.9 \pm 0.98 \mathrm{~mm}$ after slow release oxprenolol, $4 \cdot 04 \pm 0.64 \mathrm{~mm}$ after long acting propranolol, and $3.96 \pm 0.73 \mathrm{~mm}$ after conventional

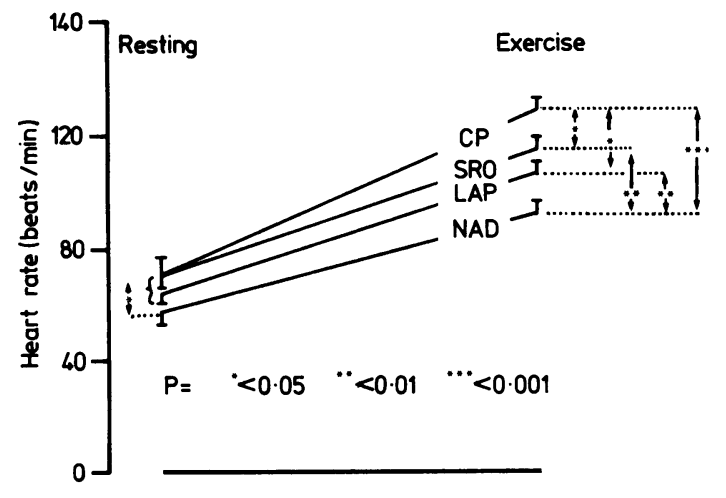

Fig. 2 Heart rate at rest and at the point of angina 23 hours after a single daily dose regimen of four beta-adrenoreceptor blockers. Statistical significance is indicated by means of asterisks between each beta-blocker. (CP, conventional propranolol; $S R O$, slow releasing oxprenolol; LAP, long acting propranolol; $N A D$, nadolol). propranolol (Fig. 3). \ST depression was significantly lower $(p<0.05)$ after nadolol as compared with the other three preparations.

\section{SIDE EFFECTS}

Bradycardia after nadolol did not produce any symptoms. One patient on nadolol and one on conventional propranolol complained of cold hands and feet and numbness. There was no objective evidence of peripheral neuropathy, and electromyographic studies showed no conduction impairment.

\section{PLASMA CONCENTRATION}

The mean plasma drug concentration was highest in the 24th hour after nadolol $(134 \cdot 6 \pm 14 \cdot 4 \mathrm{SEM})$ and lowest at $13 \pm 4 \mathrm{ng} / \mathrm{ml}$ after conventional propranolol. The high serum level of nadolol was in keeping with a significant reduction in the simultaneously studied exercise-induced tachycardia (Fig. 2), but it is of interest to note that the low level of conventional propranolol was also accompanied by a lower exercise

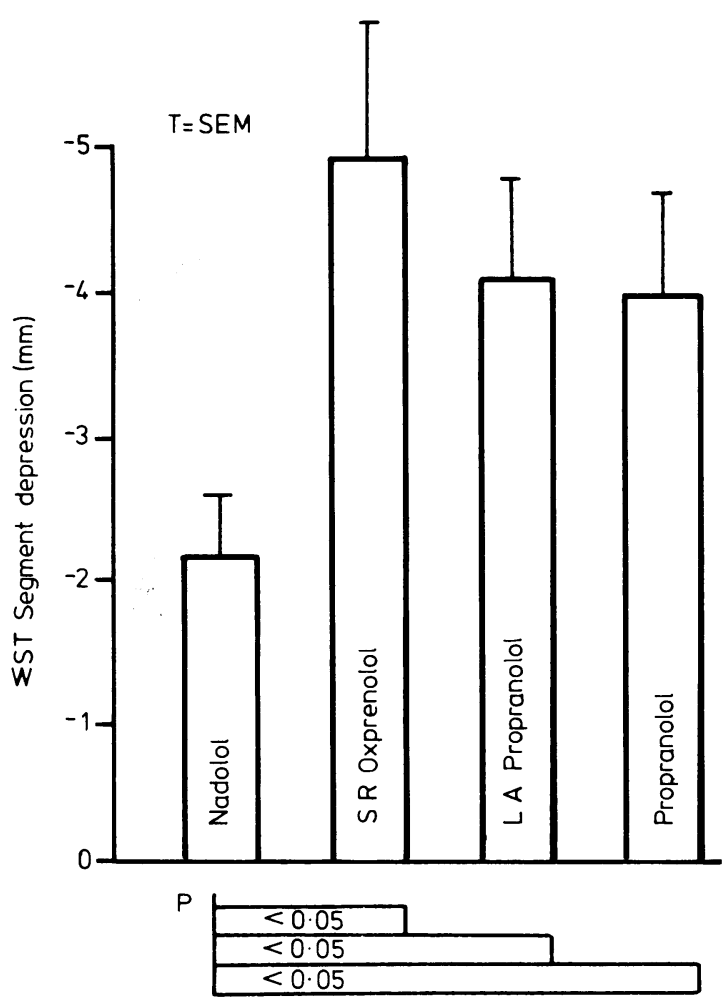

Fig. 3 Total ST segment (all leads) depression at rest and after exercise in the 24th hour after two weeks of a single daily dose regimen of four beta-adrenoreceptor blocking agents. Nadolol showed significantly $(p<0.05)$ less $S T$ segment depression as compared with the three other preparations. 
heart rate than would be expected without betablockade. Long acting propranolol and slow-release oxprenolol occupied intermediate places with the 24th hour mean plasma levels of 26 and $46 \mathrm{ng} / \mathrm{ml}$, respectively. The drug was undetectable in the plasma of four patients in the slow release oxprenolol group, one in the conventional propranolol group, and one in the long acting propranolol group.

\section{Discussion}

This study showed that there was no significant difference in the frequency of anginal attacks and glyceryl trinitrate consumption between the treatment periods. The overall patient preference was in favour of long acting propranolol and nadolol (Table 1); the patients felt better subjectively, the anginal attacks did not occur in clusters towards the evenings and early mornings (as happened with conventional propranolol and slow release oxprenolol), they were able to lead a more active life, and, with nadolol, the anginal attack rate as well as the glyceryl trinitrate consumption were less than with the other three drugs (Table 2). An interesting finding was that a single dose of conventional propranolol was as effective in controlling the frequency of angina as long acting formulations of propranolol and oxprenolol. The mean propranolol level in the 24th hour was $13 \pm 4$ $\mathrm{ng} / \mathrm{ml}$, which is capable of producing a significant beta-blockade. ${ }^{45}$ Though plasma levels of slow release oxprenolol were higher than conventional propranolol, a lower work load was achieved during the former. Other workers' data ${ }^{11}$ suggest that dose for dose propranolol is slightly more effective in angina than oxprenolol and that nadolol is more potent than propranolol. ${ }^{8}$

The absorption of slow release oxprenolol may be erratic from the gut since four of the 12 patients had no oxprenolol in their plasma in the 24th hour. As slow release oxprenolol was the mainstay of their treatment during a period in which they experienced an increased frequency of anginal attack, and since the final tablet count failed to suggest a lack of compliance, it seems likely that either the drug was not absorbed, or, for some reason, was rapidly excreted in these four patients.

Nadolol is a newly introduced beta-blocker with a long serum half-life of 16 to 24 hours. $^{7}$ This study showed that it maintained high plasma levels in the 24th hour after a single daily dose treatment and produced a highly significant degree of beta-blockade as shown by suppression of exercise induced tachycardia compared with slow release oxprenolol and long acting propranolol. The post-exercise עST segment depression was significantly lower than with the other three preparations.
Our studies indicate that when given as a single dose the antianginal efficacy in the 24th hour relates to the degree of beta-adrenoreceptor blockade achieved at that time, and $160 \mathrm{mg}$ nadolol was the most effective and $160 \mathrm{mg}$ slow release oxprenolol the least effective in achieving this.

We are indebted to Dr J McAinsh (ICI Pharmaceuticals Ltd, Macclesfield) and to Drs M E Tenneson and S B Biggs (Squibb Research and Development, Liverpool) for measurement of plasma drug concentrations, to ICI Pharmaceuticals and to E R Squibb and Sons, Hounslow, for the supply of drugs. We should like to thank Drs T M Hayes and J H Lazarus, consultant physicians, for allowing us to study some of the patients under their care.

\section{References}

1 Thadani U, Davidson C, Singleton W, Taylor SH. Comparison of the immediate effects of five betaadrenoreceptor blocking drugs with different ancillary properties in angina pectoris. $N$ Engl f Med 1979; 300: 750-5.

2 Gianelly RE, Goldman RH, Treister B, Harrison DC. Propranolol in patients with angina pectoris. Ann Intern Med 1967; 67: 1216-25.

3 Zsoter TT, Beanlands DS. Propranolol in angina pectoris. Arch Intern Med 1969; 124: 584-7.

4 Alderman ED, Davies RO, Crowley JJ, et al. Dose response effectiveness of propranolol for the treatment of angina pectoris. Circulation 1975; 51: 964-75.

5 Pine M, Favrot L, Smith S, McDonald K, Chidsey CA. Correlation of plasma propranolol concentration with therapeutic response in patients with angina pectoris. Circulation 1975; 52: 886-93.

6 Redwood DR, Rosing DR, Golstein RE, Beiser GD, Epstein SE. Importance of the design of an exercise protocol in the evaluation of patients with angina pectoris. Circulation 1971; 43: 618-28.

7 Vukovich RA, Foley JE, Brown B, et al. Effect of beta blockers on exercise double product (systolic blood pressure $\times$ heart rate). Br $\mathcal{F}$ Clin Pharmacol 1979; 7, suppl 2: $167 \mathrm{~s}-72 \mathrm{~s}$.

8 Lee RJ, Evans DB, Baky SH, Laffan RJ. Pharmacology of nadolol (SQ 11725), A beta adrenergic antagonist lacking direct myocardial depression. Eur $\mathcal{F}$ Pharmacol 1975; 33: 371-82.

9 Friedman $M$. Use of ranks to avoid the assumption of normality implicit in analysis of variance. Fournal of the American Statistical Association 1937; 32: 1216-25.

10 Wilcoxon F, Wilcox R. Some rapid approximate statistical procedures. Lederle Laboratories, 1964. New York.

11 Thadani U, Davidson C, Singleton W, Taylor SH. Comparison of five beta adrenoreceptor antagonists with different ancillary properties during sustained twice daily therapy in angina pectoris. Am $\mathcal{F}$ Med 1980; 68: 243-50.

Requests for reprints to Dr M A Mir, University Hospital of Wales, Heath Park, Cardiff CF4 4XW. 